\title{
THINKING STRAIGHT ABOUT CORPORATE LAW REFORM
}

\author{
Bayless MANNING*
}

"Corporation" has been an inflammatory word in American political history for more than a century. Recently, as this symposium manifests, the embers of controversy about corporations have again been fanned by a number of highly publicized scandals and by calls from a variety of quarters for a new round of corporate law reform. Some strident voices charge that the American corporation and American corporation law are in a condition of crisis that must promptly be met by major changes in the present system of corporate governance and by new state and federal regulation or federal chartering.

The high noise level of these criticisms attracts public attention. But serious discussion of these matters calls for more than noise. We need to identify accurately what it is about existing corporation law that needs reforming, why it needs reform, what reform would best respond to the supposed need, what are the best instruments for achieving the allegedly needed reform, and what would be the costs and negative side effects of such reform. Ultimately, rational public policy debate demands that participants talk about one thing at a time and that if $A$ and $B$ are different, they not be treated as though they were the same. Those principles are not being followed in today's corporate law reform, as appears in the course of this article. Although I have, along the way, interjected some personal views on some of the issues discussed here, it is not my primary purpose to convert the reader to my own opinions. My hope is to help sort out the complex issues of corporate law reform and contribute analytically to the process of thinking straight about them.

I

\section{Some Preliminary Comments About Corporations and Charters}

There are a number of reasons why corporations are a natural, even inevitable, source of public irritation and tempting targets for the attentionseeking politician and journalist. The most fundamental reason contains something of a paradox. Precisely because America's corporations have proven to be a remarkably effective social adaptation, we look to them to perform many of the most basic economic functions of the society; and because those functions have generally been well carried out, the American pub-

\footnotetext{
* Partner, Paul Weiss, Rifkind, Wharton \& Garrison, New York, N.Y.; dean. Stanford Law School, 1964-71; president, Council on Foreign Relations, 1971-77.
} 
lic has very high expectations of performance. As a result, almost any unwelcome economic development or unpleasant business encounter experienced by John $Q$. Citizen-a rise in insurance rates, a decline in employment, an interruption of electricity, a late aircraft arrival, a malfunctioning appliance, a disappointing wage level, a bankruptcy of a small business, poor service in a hotel-is likely to be laid at the door of some corporation, or "the corporations." Business executives sometimes complain that they are not properly appreciated by the public for the contribution which their companies make to the common weal; those executives just do not understand that the basic reason the corporations get blamed so much is that they do so much.

A second major contributor to the public's attitudes toward corporations is, simply, ignorance of economic affairs. The nation's educational system does an appallingly poor job of teaching how the nation's economy operates, what business enterprises do, how they do it, what they provide, how they are funded, what their return is, how the return is distributed, and so forth. Unlike the unavoidable factor mentioned first, the lack of public understanding of this field could be, and should be, mitigated by better educational programs.

These two factors, compounded by the sheer economic size and visibility of some enterprises, provide an environment of public attitude that is predisposed against the large enterprise. Against that background, and actively aggravating the situation, is the undeniable fact that business executives as a class are probably about as good and as bad as other classes of human beings and that despite the impressive accomplishments of American corporations and their managers, their history is marred by isolated but regrettably numerous instances of actual fraud, deception, economic bullying, bribery, theft, disregard for employees, personal aggrandizement, distribution of dangerous products, and-the most frequent sin-arrogance and shortsightedness. Whenever such reprehensible conduct is brought to light, it is seen by the. public through the magnifying glass of the public's generalized negative attitude toward "the corporations," and a new wave of reform is born.

I have noticed, however, that public attitudes toward the subject of corporations are frequently tinctured by deep-seated suspicions that are unrelated to the actual conduct of business enterprises. Those apprehensions flow from certain vague images of corporations that are, in turn, rooted in conceptual misunderstanding and echoes of medieval history. In the hope of clearing the air of these ghosts, I would like to commence with some rudimentary observations about corporateness and about corporate charters. This slow start entails some risk of trying the reader's patience, but real issues in this field are sufficiently numerous and difficult that there is little reason to import false ones.

\section{A. Corporations and Corporateness}

A corporation is an organizational form. It is a particular legal way of organizing an ongoing operation, as a partnership is a particular legal way of 
doing so. What incorporation of an enterprise amounts to in substance is that a piece of paper conforming to the corporation act of some state is put on file with the designated state official, certain persons are designated as the board of directors, and if it is a commercial enterprise, certain persons hold an investment interest in the enterprise of a type that is legally designated "shares." Strictly speaking, a corporation is not an economic enterprise; it is a form in which some enterprise is organized. Large enterprises (such as a large auto manufacturer), medium-sized enterprises (such as a fabricator with a single plant hiring 200 employees), and small enterprises (such as a two-man barber shop or even a single practising physician) that differ in all other respects may have one feature in common: each may be a corporation. ${ }^{1}$

Indeed, the term "corporation" is even more generic than would appear from the last paragraph. All the enterprises instanced there were commercial. But charitable foundations, churches, cemetery associations, consumers' and producers' cooperatives, etc. are also usually cast in corporate form. Furthermore, the term "corporation" is not limited to the private sector. Municipalities are corporations; public-private hybrids like Comsat and the Federal National Mortgage Association (Fannie Mae) are incorporated; public enterprises, such as the Tennessee Valley Authority and the Panama Canal Company, are corporations; and even international organizations of sovereign nation-states, like the World Bank, may be incorporated.

From being told that an object is a cube, one can infer nothing about its size, weight, color, smell, or value; from being told that an enterprise is a corporation, one can infer nothing about its scale, character, bargaining power, strategic importance, functioning, or value. Thus, to inveigh against or applaud "corporations" without specifying particular enterprises, or at a minimum a class of enterprises sharing common substantive attributes, is simply to make noise. Most commentators who polemicize against, and politicians who run against, "corporations" have in mind not corporations at all but a particular handful of large-scale commercial enterprises. It may be that the business conduct of some enterprises should be subjected to additional regulation, but it is not because they are corporations. Correspondingly, if one's purpose is to modify the conduct of those enterprises, amendment of state corporation laws, which are of general applicability to all commercial incorporated enterprises, will certainly be misdirected.

1. In fact, only a few incorporated enterprises are large. For example, in Connecticut, which in this respect is typical of other states, there were on June 30, 1976, approximately 43,254 domestic corporations active in the state and 6,600 foreign corporations authorized to do business there. As of September 30, 1976, only 221 of these 50,000 companies, or less than one-half of 1 percent, were large enough to be required to file regular reports with the SEC. Telephone conversation with John T. Maloney, Director, Corporations Division, Secretary of the State's Office, Hartford, Connecticut (Dec. 9, 1977). 
The flow of lucid discourse about incorporated enterprises is further muddied by public misunderstanding of the nineteenth-century statement of legal doctrine that a corporation is a "person" or, what is worse, a "fictitious person." The public has always felt, or been taught to feel, that there is something inherently unnatural, spooky, and Frankensteinian about the notion of a fictitious person-to suspect that it is some kind of gimmick by which shady incorporated slickers mulct honest unincorporated yeomen. Well, there have been plenty of thieves and crooks in business enterprises through the ages; but neither their crookedness nor their predatory successes were attributable to the fact that the corporation is said at law to be a fictitious person. To say that a corporation is a fictitious person means nothing more or less than that it is convenient for some purposes to treat the multiplicity of interests in the enterprise as a collectivity-as a single entity. As a matter of legal history, the corporation came to be viewed as a person as soon as the law recognized that "it" could hold title to property and could sue and be sued. The law does the same thing when it groups together millions of people east of the mouth of the Hudson River as a collective entity, New York City, for such indispensable activities as issuing bonds, entering contracts, bringing law suits, and electing officials. New York City is a necessary collective political and legal abstraction of eight million human beings. In the same way, a commercial corporation is a collective legal abstraction grouping together a variety of economic interests in an economic enterprise. ${ }^{2}$

A decision to treat a collectivity of interests as a unit is a matter of administrative convenience and nothing else. Thus, for example, one may view our present corporate tax system as good, bad, or indifferent, but it is meretricious to defend it by arguing that the corporation should pay a tax because it is a person and equally meretricious to attack it by arguing that the corporation should not have to pay a tax because it is only a fictitious person.

In sum, a corporation is simply an organizational form, a legal carapace that surrounds infinite varieties of enterprises and institutions. That generalized organizational form-not the conduct of the varieties of enterprises that adopt it-is the subject of our corporation laws.

\section{B. Charters and Chartering}

In the long-ago of French and English history, charters for enterprises were granted by monarchs, just as were feudal tenures, titles, and land patents. Such corporate charters often granted economic monopoly rights, either

2. Readers with a taste for history will be interested to note that the progenitor of the legal concept of the modern corporation was the municipal corporation. The major contributions that the concept of corporateness brought to the law were that title to property held by a collectivity such as the City of London could be continued in spite of the mortality of individual Londoners and Mayors and that institutional decisional machinery could be regularized on an ongoing basis in law. 
in a line of enterprise or in a geographic area, and vested limited semigovernmental powers in the corporation. From the perspective of the Crown, the technique of royal incorporation was a logical and generally successful adaptation: others invested capital in the enterprise, others invested their energy and careers, others shouldered burdensome administrative chores in remote climes, the nation's commerce and industry were advanced-and the Crown shared in the returns. Necessarily, each charter was hand tailored and unique, especially insofar as it granted monopoly powers. Equally necessarily, the number of such charters was very small.

In the newborn United States of America, it might have been argued with historical consistency that the former charter-granting powers of the Crown were inherently vested in the executive branch of government. But it seems not to have been so argued, and the nation embarked at once upon a system under which corporate charters were granted by state legislatures. This system did not work very well. It soon became evident that legislative bodies were not well equipped to negotiate or draft corporate charters and to enact what were in effect private bills. It was inevitable that in time special pressures, favoritism, and even overt bribery would be brought to bear on legislators by persons seeking corporate charters-and they were.

But something else more basic and important also occurred. In the burgeoning commerce of the new Republic, and especially as the Industrial Revolution came alive, a substantive change occurred in the objectives of those who were seeking charters. The entrepreneur who wanted to build a new toll bridge had to have the permission of the state, and to make the enterprise feasible, he had to have a monopoly for some distance up and down the river; such an entrepreneur needed a charter of the old style, handcrafted to provide that monopoly. The same thing was true, to a slightly lesser extent, of the railroad line. But if the contemplated industrial enterprise was to be a soap factory or a ship yard or a spinning mill, then none of the elements of monopoly or of semigovernmental function was required. With increasing frequency, those who wanted corporate charters simply intended to enter a competitive business arena. They wanted the charter as an administrative mechanism to enable them to attract capital, to provide for continuity of the enterprise, to provide a machinery for decisionmaking, and (later on) to limit the economic exposure of those who invested their capital as shareholders, as (in a different way) the exposure of those who invested their capital as creditors was limited.

The resultant of these two forces was predictable and constituted sound public policy. It became a key feature of post-Jacksonian populist reform to slay the dragon of legislative favoritism by making corporate charters available to anyone who asked for one. It had become possible to shift to such a generalized system because corporate charters were no longer linked to monopoly grants. The basis was thus laid for the general corporation acts that 
were swiftly and widely adopted by state legislatures throughout the country beginning in the 1840's. Thereafter responsibility for granting charters (or articles, or certificates, of incorporation, as they came to be called) was transferred from the legislative branch to an administrative officer of the state. It was his duty to issue articles of incorporation to any person who requested them and complied with simple prerequisites set forth in the state's general corporation act.

It is simply demagogy for anyone today to proclaim with an air of indignant discovery that state corporation laws do not regulate the economic conduct of enterprises and are easy to comply with. Our corporation acts were expressly so designed over a century ago-as the product of a wave of corporate law reform-to make available to everyman the administrative convenience of the corporate form.

In the usual case today, anyone who obtains a certificate of incorporation simply proceeds to go into business. A few lines of economic activity, however, such as public utilities and banks, have long been carved out of the general field of competitive enterprise and brought under direct regulatory control by the government as business affected by the public interest. Analytically, two avenues of organization are possible for a company in a regulated industry. The first route, the old-fashioned way, is to proceed by special charter. In Connecticut, for example, it has remained customary to create new insurance companies through a special statutory chartering process. The alternative for corporate formation in a regulated industry is illustrated by the airlines industry: one may incorporate an airline company in any state under a general corporation act, but the enterprise will not be permitted to enter into the interstate airline business until approval and route awards have been granted by the Civil Aeronautics Board.

The avenue of the special charter is clumsy. It requires a separate procedural framework for each industry and compels the legislature to perform a function that is better performed by an administrative agency. The second approach is more functional, as it leaves to the general corporation act the routine formalities of formation and procedure while remitting to a specialized regulatory agency the substantive regulation appropriate to the industry in question.

It has taken a long time-and is still taking time-for the function of general corporation acts to be widely understood. It is almost enough to make one believe in the existence of a continuing cultural memory to note how readily critics of corporate behavior revert to ancient thought patterns and call for the sovereign to grant corporate charters that will include the special regulations that the reformer holds dear. Advocates of that approach never make clear why such regulations must be built into that vestigial medieval document, the charter. The reasons, I fear, are subconsciously grounded in atavistic images of the corporation as a person, born from the forehead of the sov- 
ereign, an invisible, immortal, and dangerous creature-but one that can be genetically restrained by programming it with special DNA instructions at the moment of its birth. Such metaphorical thinking has nothíng to commend it.

Congress and state legislatures have commonly imposed curbs on the conduct of incorporated enterprises through general legislation rather than through charter provisions. For generations, administrative agencies have regulated monopoly industries effectively without resort to the antiquarian process of corporate chartering. Meanwhile a century and a half of experience has gone into developing our sophisticated general corporation acts in the states to supersede the machinery of special-charter incorporation. Whether society should impose additional substantive restraints, federal or state, on the behavior of large-scale enterprises is an important subject for public debate; but that debate is simply obscured by introducing the extraneous topic of charters, and further, in most instances the debate has nothing to do with the subject matter of corporation laws.

II

\section{Species of Corporate Law Reform}

As we leave these preliminary observations and turn to the task of sorting out the shotgun charges against modern American corporation law, the key question to ask any reform advocate is: Precisely what is it about today's corporations or corporation law that seems to you so antisocial, dangerous, or unjust? As one reviews the body of published criticism of the modern corporation with this question in mind, no less than nine separate answers, or species of answers, can be identified. The balance of this article is devoted to a review of these nine species. Perhaps there are even more than nine, but nine is quite enough to demonstrate that the complaints about modern largescale enterprise are not integrated but disparate-are not cumulative but discrete. Scattershot solutions will therefore not do. Each species of criticism must be examined and weighed separately, must stand or fall on its own merits, and if proven, must be addressed by remedies hand-tailored to the particular purpose.

\section{A. Corporate Reform Species I}

To one group of critics of large corporate enterprises it seems fundamentally immoral and unwise to permit private-sector companies and those who manage them to make basic decisions about economic production, resource allocation, and investment that are of great importance to everyone in the society. In this view of the matter, the social importance of these financial and economic decisions is so great that they ought to be made by govenment rather than by private institutions responding to market forces.

The viewpoint of group I critics, of course, represents a fundamental challenge to the basic concept of a free-market economy. If one assumes the valid- 
ity of this position, what kind of political and legal changes are called for? Obviously, the answer would be that the nation needs some kind of national planning agency; new governmental machinery to mandate price controls, rationing, and ordering of capital investments; and some degree of nationalization. In the light of the experience of dozens of countries over the last fifty years, I find it hard to believe that such a program would inspire much enthusiasm in the United States. But for present purposes the point is that this species of complaints about corporations, and their putative answers, have nothing to do with the field of corporation law. It is an absolute non sequitur to contend that the management of large corporations should not be able to decide whether to reduce steel production and therefore what is needed is federal chartering or reform of state corporation laws. Free-market economy versus socialism is a valid, debatable issue, but it is a wholly independent question that should not be smuggled in under the guise of discussion about corporate reform.

\section{B. Corporate Reform Species II}

In the view of reform advocates of species II, large business enterprises ("the corporations") are inherently rich, immoral, ruthless, and continually engaged in greedy depredations upon the public, such as polluting the environment, cheating consumers, or oversugaring the breakfast cereal. In this perspective, big oil companies invented the energy crisis in order to raise their prices, and increases in interest rates, insurance premiums, and utility bills are attributable to the avarice of banks, insurance companies, and utility companies. It is characteristic of this species to view profit as plunder. Supply and demand are little understood by these critics, and the function of capital investment even less understood. Notably, too, the corporation is not perceived as a collective institution through which revenues are distributed among multiple claimants but as an anthropomorphic creature that grows fat by accumulating profits and wealth for "itself."

As species I is populated by socialists, so species II is the home of the native American populist. He would not eliminate corporations because he sees them as productively efficient, but he believes they are infinitely rich and infinitely malevolent and if left alone in the dark will steal the pennies from the church poor box.

If one holds these views, what direction should one choose for corporate reform? The allegedly deplorable moral character of large enterprises cannot be remedied by tinkering with their internal organization or state corporation laws. What is obviously needed is taxation and economic regulation, more taxation and economic regulation, and still more taxation and economic regulation. In addition, a recurrent impulse is to invoke direct control of pricing, though our experience with that device has hardly been satisfactory. Species 
II reformers will be found in the forefront of almost any proposal to regulate or tax business enterprises.

\section{Corporate Reform Species III}

Members of species III hold a generally high regard for the economic contribution made by American corporate enterprises and a free market, but they nonetheless believe that society must, on an issue-by-issue basis, step in to control particular aspects of corporate conduct and to set the ground rules within which all business enterprises are required to operate. Hardly anyone, I suppose, disagrees with that proposition so generally stated. As new problems arise or are newly perceived in public debate, however, those who belong to species III divide on the question whether new regulation is needed and if so, what kind. When a sufficiently strong case is made to convince a large segment of species III that new substantive controls on business are needed, they join species I and II critics-who are ever ready to increase controlsand another block of restrictive legislation is added to the pile accumulated over the last century.

The 1970's have been a period of intense activity for corporate reform of the species III variety. The nation learned the words "environment" and "ecology" and a large share of the responsibility for environmental degradation was attributed to large-scale enterprises. Organizations championing the small consumer came to the fore. The flotsam and jetsam that floated to the surface following the sinking of $\mathrm{Mr}$. Nixon included evidence of illegal corporate political contributions on a substantial scale. The Arab oil embargo temporarily dislocated the United States economy and many found it strange that thereafter the profits of some U.S. oil companies rose, even temporarily. Numbers of U.S. enterprises were found to have made questionable payments overseas, and in a few instances, to have bribed foreign officials. The consequence of these events has been a wave of new substantive restraints on enterprises, some enacted by the Congress and state legislatures and others sketched freehand by the courts at the behest of an aggressive bar and selfdesignated public-interest law firms acting on behalf of real or constructive clients. Federal and state administrative agencies have vied with the legislatures and courts in adding new constraints upon the conduct of commercial enterprises and in requiring increasingly detailed public disclosure of facts and figures about them. The Internal Revenue Service has joined in, using its own special dentist's tools to extract information. Almost without knowing it, we have for some years been living through a period of major corporate reform. Future historians are likely to see the 1970's as ranking in importance with the reform waves that occurred in the first and third decades of this century. Where abuses of corporate conduct have been found, our public institutions have reacted so that such misconduct will not recur or will, at least, 
be extremely risky for those who perpetrate it.

It may be hoped-though in this I am not wholly optimistic-that the nation's corporate managers and directors will have learned from the experience of recent years that in the long view reprehensible business conduct can only arouse the latent antibusiness animus that is harbored by so many journalists, academics, legislators, and general citizens. If that lesson is not learned, the nation's enterprises will certainly experience a continuing pile-on of government regulations, mandates, and constraints. The ultimate danger is, of course, that at some point the patient will not be able to survive the therapies. At some point, the internal efficiency and flexibility that have made American enterprises such a successful institutional adaptation can be diluted or burdened to a degree where they can no longer function effectively. ${ }^{3}$ At that point, the real victims will be not the corporations but the economy of the United States, our citizenry that relies upon that economy, and the interdependent economies of other nations. ${ }^{4}$

The immediate point at hand, however, is that the concerns of corporate critics of the third species relate to substantive behavior of enterprises. Where antisocial behavior is found, the society's response should be to strengthen and rigorously enforce particular substantive laws forbidding it. If one wishes, one may call that social response a variety of corporate reform, but it does not relate to corporation laws or to corporate charters. ${ }^{5}$

\section{Corporate Reform Species IV}

As a fourth group of reform-minded critics sees it, large-scale enterprises are monopolists that squeeze out competition and devour small enterprises. This attitude has appealed to Americans for a long time. Out of it have come the Sherman and Clayton Acts and a continuing contest between the major

3. For example, is it clear that American companies operating overseas, already subject to stringent U.S. antitrust and tax laws, will not be put under further competitive disadvantage by new extraterritorial U.S. prohibitions of "expediting payments"? There can be no argument in favor of bribing governmental officials at home or abroad; it is illegal everywhere in the world and cannot be condoned. But expediting payments are endemic to the commercial life of many societies around the world in which U.S. companies must compete against local concerns and large non-U.S. transnational companies. If the Congress and the American people wish to embark upon another campaign of world improvement-a kind of commercial Wilsonianism-that is undoubtedly admirable and one may hope for some success; but it is troubling, and characteristic, that in the debate that attended the enactment of the Foreign Corrupt Practices Act of 1977, Pub. L. No. 95-213 (1977), there was little evidence that the Congress or the public was sensitive to the fact that a balance must be struck between the desire for a better world and the necessity to live in this one. It has also not been an edifying sight to observe the relish with which some American politicians and polemicists have pilloried U.S. business executives whose villainy was that they operated overseas on the principle, When in Rome. . .

4. In another article, the author has explored this concern in the broader context of the general state of regulation in modern American society. Manning, Hyperlexis, Our National Disease, 71 Nw. L. Rev. 767 (1977).

5. This point is a bit overstated here for simplicity, and should be read in the context of the discussion on page 27 infra. 
political parties for the honor of being more antitrust. The ideal of the small businessman has a deep-seated attraction that has led to special protective laws like the Robinson-Patman Act and agencies like the Small Business Administration.

It is a fair topic for debate whether existing state and federal antitrust laws are too stringent or not stringent enough and whether they are properly targeted and adequately clear. But there is no real argument about the process through which legislatures and courts should deal with these problems; setting the ground rules for competition is simply one instance of the sort of public policy issues discussed in section $\mathrm{C}$ above. The solution to problems of unfair competition does not lie in amendment of corporation laws, and it would not increase the effectiveness of the Sherman Act to require it to be recited in certificates of incorporation.

\section{E. Corporate Reform Species V}

A fifth group of critics of modern American large-scale enterprises are primarily concerned about a completely different group of people: corporate investors. Today's American investorate can hardly be equated with the idle rich. Tens of millions of persons are direct holders of stocks and bonds in this country and perhaps as much as eighty per cent of the adult population are indirect holders or beneficiaries of such investment interests through pension funds, insurance policies, trusts, and mutual funds. In a market economy, the decision whether or not to invest in an enterprise lies with the investor. But in order for him to be able to make decisions intelligently and to invest on a fair and equitable basis, the marketplace must be free and relevant information must be available. Species V critics feel that we have not gone far enough in our securities laws, our accounting rules, our disclosure practices, or our legal doctrines to achieve those conditions.

No informed person would argue that our state and federal securities laws and regulations are at a point of perfection or that modern accounting practices cannot be improved. An atypical fraud like Equity Funding occasionally goes too long before detection; more frequently important information is disclosed to the marketplace later than it ought to have been. These are among proper subjects for attention.

But the fact is that beginning especially with the Securities Acts revisions of 1964 our securities laws have been experiencing continuous and rapid development. Although recent Supreme Court decisions have reflected second thoughts about the virtually unlimited scope of rule 10b-5 liability implied by earlier lower-court decisions, the rate of change in the securities field as a: whole has accelerated of late as the SEC has aggressively pressed forward on the issues of competitive commissions rates for brokerage firms, creation of a national securities market, and additional disclosure requirements for reporting companies. At least equally rapid changes have overtaken, or been im- 
posed upon, accounting practices during this period through the work of the Financial Accounting Standards Board, the SEC, and less directly, the courts.

There has been no failure on the part of public agencies to call large incorporated enterprises to task where circumstances indicate that more stringent guidelines should be laid down to protect investors. The existing regulatory system is evolving and responding effectively to new needs as they are perceived. There is every reason to believe it will continue to do so. It is simply not supportable to contend that the deficiencies which group $\mathrm{V}$ critics believe they see constitute a crisis that calls for radical reform.

\section{F. Corporate Reform Species VI}

In 1932 it was proclaimed in print (and it apparently came as a shock to academic circles at the time, though it is difficult to reconstruct why) that corporate managements have more to do with corporate business decisions than shareholders and that shareholders usually vote overwhelmingly in favor of management's recommendations. ${ }^{6}$ Ever since then, a group of corporate critics-species VI-have been volubly pressing for more participation by common shareholders in corporate affairs, more "shareholder democracy." The concern of these critics is not investors as a whole; it is the subclass of investors who hold common stock.

The shareholder democrats have won some battles over the years. Proxy statements have expanded, even exploded, in size and detail. The range of permissible shareholder initiatives for shareholder votes has expanded substantially. The popularity of classified boards of directors has declined and cumulative voting is more widely available. Shareholders today often vote on the choice of company auditors. But what advocates of shareholder democracy have been least successful in doing is arousing the interest of shareholders in their cause. It turns out that shareholders in major enterprises do not buy shares in order to play town-meeting games or in order to give vent to their managerial impulses or to voice their political preferences. They buy their shares as an economic investment; they hold them as long as they continue to believe that the investment is promising, and during that period they are quite willing to follow the leadership of the company management; if they become disenchanted with the prospects of the investment, they sell their shares as rapidly as they can.

Intellectual cousins of the critics discussed later as species VIII, proponents of shareholder democracy adopt as a premise, tacit or express, that a large commercial enterprise is, or ought to be, essentially the same as a political institution. They also adopt two other minor premises: The first is that the

6. See A. Berle and G. Means, The Modern Corporation and Private Property (rev. ed. 1968). 
only legitimate basis for institutional decisionmaking is the one-person-onevote, majoritarian town-meeting model; the second is that the only proper constituency for participating in their imagined corporate town meeting are the persons who hold certificates representing that particular form of investment called common stock. (Members of species VI also run this second principle backwards, asserting that any investment interest that is called common stock should in the nature of things have a voting franchise and therefore nonvoting common stock is immoral.) In this view of the world, common shareholders should have a larger hand in running the affairs of major enterprises, and corporate reform should be pursued in the direction of more shareholder plebiscites, more information distributed to shareholders, and the like-a pattern of reform that is wholly distinct from those described earlier.

As appears later, I believe the axioms of group VI to be unsound, but for present purposes two other observations are more important. The first observation is that as we come to the criticisms of species VI, we are at least getting closer to the subject matter of corporation laws-the internal governing machinery of the incorporated enterprise. The second observation is that not even the most perfervid shareholder democrat would claim that these issues of shareholder participation constitute a national crisis or even make up a significant fraction of the public policy issues that relate to large-scale business enterprises. The American public as a whole has never heard of these questions, and at least ninety-five per cent of those who hold shares in large companies-those who are supposed by the shareholder democrats to be the victims of disenfranchisement-consistently use the franchise they have to vote in favor of management, their supposed depredators. In such circumstances it is difficult to argue that sweeping reform of the existing corporate legal system is called for on the grounds urged by critics of species VI.

\section{G. Corporate Reform Species VII}

Whereas Berle and Means saw the mass of shareholders as victims whose franchise had been usurped, some reform-minded critics of today see the major problem of corporation law as the need to protect minority shareholders from bullying by the majority. As the shareholder democrats of species VI extoll the virtues of majoritarianism, the voices of species VII plead the civilliberties case of minoritarianism, arguing for the inviolable rights of the individual shareholder, even where all the others have voted against him.

A sophisticated spokesman for this general viewpoint is former SEC Chairman, now professor, William Cary. His arresting phrase "race to the bottom"7 expresses his concern that each state legislature (especially Dela-

7. Cary, Federalism and Corporate Law: Reflections Upon Delaware, 83 YALE L.J. 663, 666 (1974). 
ware's), eager to attract new incorporations in order to collect franchise taxes, is moved to set lower and lower standards of protection for minority shareholders. He feels that the only way to halt this alleged race of permissiveness is to enact a federal statute superseding state laws to set minimum procedural requirements for large enterprises in order to protect shareholders, especially minority shareholders. He does not specify what procedural provisions should be included in such a statute, though he suggests a few as candidates.

Professor Cary has a second criticism of things as they are. He believes that the Delaware courts-the locus of so much important corporate litigation -are insufficiently sensitive to the claims of minority shareholders and insufficiently stringent in setting fiduciary standards for majority shareholders and for corporate directors and managers. Here again, he believes the state courts are engaged in a race of permissiveness. He concludes that a federal minimum-standards law is needed to set a high nationwide fiduciary standard for corporate insiders. He does not say what kinds of provisions he would suggest to achieve this purpose. Concerned about the litigation load that such a federal statute would dump on the federal courts, he suggests tentatively that litigation under the new statute be left with the state courts with certiorari jurisdiction in the Supreme Court to settle conflicting interpretations.

Perhaps Professor Cary in a fundamental sense will prove to be right. In the matter of corporate financial disclosure history affords us one striking instance in which state legislatures failed to act in part because no single state could impose substantially more stringent requirements than others; ultimately the SEC had to be created by the Congress to raise the national water table of corporate disclosure. Moreover, I think it is probable that regardless of ideological preferences the necessities of an integrated national economy will increasingly induce the federal government to intervene to achieve national uniformity of standards in manufacturing and commerce. Thanks to the wisdom of the Founding Fathers, the United States has avoided Balkanization through internal tariffs, and the problem of conflicting taxes has at least been mitigated. But it is quite likely that we are entering a new era in which the Supreme Court will be called upon repeatedly to invoke federal preemptive power to knock down variations of substantive economic regulation imposed by fifty states in favor of uniform national standards.

Corporate managers will be among those who will most urgently need uniform standards to enable them to produce goods and market them. A day is dawning when the nation's business lobbies will appear in Washington to argue for aggressive federal regulation to preempt the field and relieve them of the impossibility of complying with a multiplicity of state regulations. Similarly, federal legislation on environmental issues offers an example of national standard setting to prevent competing states from using lax codes in an attempt to attract industry. 
But despite these generalizations about the changing course of our federal system, it is questionable whether Professor Cary has made out his particular case. To pursue the matter in detail would require another article. But it is interesting to note that none of the provisions he suggests as candidates for inclusion in a federal statute on minimum corporate procedural standards is based on actual instances of corporate misfortune. The nation's antitrust laws, our Blue Sky laws, and the Securities Acts of 1933 and 1934 were born out of bitter experience and actual injury. But when one turns to questions of internal corporate procedure, the entire conversation must be conducted in terms of "ought." There is nothing in the sky that informs us that $66^{2 / 3}$ per cent is a good number while 51 per cent is a bad number for purposes of shareholder voting on mergers. No commentator or scholar ever attempts to establish, nor could it be established, that a higher numerical vote requirement would save incorporated enterprises from unwise mergers (whatever that might mean), even if one were to assume that the prevention of unwise economic transactions is a proper legislative function. Similarly, it cannot be shown empirically that nonvoting common stock is vicious and should be forbidden, while nonvoting (or voting) preferred stock and nonvoting (or voting?) debentures are moral and favored by public policy; to my eye, and that of the marketplace, all three are simply investment variants, useful in appropriate situations. The same is in general true of the other procedural propositions suggested by Professor Cary for inclusion in a federal minimum-standards statute. They proceed from an a priori political image of what the decisionmaking process of an incorporated macroenterprise "ought" to be. Such oughts (which are based mainly upon the historically familiar ${ }^{8}$ plus a classic and healthy American sympathy for the outnumbered) provide material for debates among professionals but do not make a compelling case for a realworld crisis calling for radical reform.

Further, there is considerable doubt about the basic assertion that state legislatures are engaged in a race of permissiveness to attract incorporations. The most recent major corporate law revision in the United States was made by California in 1975. The California legislature did not adopt the Delaware statute, did not strive to outdo Delaware in permissiveness, and in fact increased the level of regulation in some respects. Similarly, the successive modifications of the Model Corporation Act, the predominant corporation act in the country, have not sought to race Delaware to the bottom. Delaware has over several generations made a specialty of incorporation (corporations are among the few things for which there is always plenty of space in a tiny state)

8. In fact, as the author has argued elsewhere, the pattern of shareholder voting rights contained in our corporation laws is based almost entirely on history plus an archaic jurisprudential view of the corporation, with almost no attention paid to the reality of economic transactions. See Manning, The Shareholder's Appraisal Remedy; an Essay for Frank Coker, 72 Yale L.J. 223 (1962). 
and corporate franchise taxes make up a significant part of that state's revenues. But that situation is atypical. For most states, corporate franchise taxes based on local incorporation (unlike the state's corporate income taxes) provide an insignificant percentage of the state's revenues; no matter what corporation laws those states adopt they cannot expect to attract such a flow of new incorporations as to add materially to the state's tax income. From the perspective of tax revenues, states do far better to attract the business operations of enterprises, wherever they may be incorporated. Other states have little tax incentive to engage Delaware in a chase for incorporations.

States should also be further dissuaded from entering into a race with Delaware by the recognition that no matter what statute they pass they can never provide one of the most important assets that Delaware offers, a corpus of sophisticated commercial case law and a judiciary that is educated and literate about business affairs. Professor Cary points out with some asperity that many members of the Delaware judiciary came out of corporate practice. To my mind that is an enormous advantage. Corporate litigation can be a very unsatisfactory experience-whether one is representing or suing management-when the proceeding is before a judge who has spent his practice years in work unrelated to the complex field of contemporary corporation law and when the local case law in business matters is antique and spotty. If Delaware were to repeal its corporation act tomorrow and substitute that of any other state, practitioners with a long view would still continue to incorporate in Delaware because of the experience of the state's administrative officials and judiciary in corporate matters.

As for the claim that Delaware's courts have little compassion for minority shareholders and underestimate the importance of high fiduciary standards for corporate management, it must be said that no demonstration to that effect has been made. And no evidence has been adduced to show that shareholders or the treasuries of Delaware companies have been visited by disaster as a result of misbehavior condoned by that state's judges. Then, too, any general legislative statement of corporate fiduciary principles would ultimately have to be applied to real situations by courts; would the fiduciary instincts of Delaware's judges become more acute if such a statement were to be implanted in the U.S. Code?

As I read the history of corporation law over the last twenty years, a stream of securities regulations and lawsuits against corporate executives, directors, accountants, and lawyers has steadily built up a coral reef of law for the protection of the individual investor and the minority shareholder. In recent years the SEC, the federal courts, the state courts (including Delaware's), and the segment of the bar that specializes in shareholder suits have drawn upon the open-ended due process clause of corporation law-rule $10 \mathrm{~b}-5$ - to reform what may be called the tort law of corporations as thoroughly as, if 
not more thoroughly than, it could have been reformed legislatively. The case-by-case process has the advantage that lawsuits involve real circumstances rather than hypothetical scripts and are addressed to disputes over real economic interests rather than abstract oughts. When in such a case a judge articulates or refines a legal proposition condemning certain conduct by the enterprise or by its managers, directors, or professional advisers, he has the advantage of seeing before him a real rather than imagined example of behavior. Such step-by-step development is not dramatic and does not satisfy the urge of some for publicly spotlighted corporate change. But surely, steadily, and soundly it reforms the law. In the corporate field, that process of continuing reform has been active during the last generation and there is every reason to believe that it will continue.

It is also fair to ask whether it is really necessary or desirable to require that all large corporate structures be the same. There is some variation among state corporation acts, and while Delaware is favored by lawyers selecting a state to incorporate a new enterprise, every state has many enterprises incorporated under its statutes, some of them large. State corporation laws have evolved incrementally over the last 150 years, recently under the magnetic pull of the successive versions of the Model Corporation Act. That healthy evolution would surely be stunted in the future if a single procedural model were set in concrete by federal legislation. Professor Cary's proposal for a federal minimum-standards statute is limited to large-scale enterprises, but if such a statute were in place it would be only a matter of time before its jurisdictional reach was extended to cover a wider spectrum of enterprises. That outcome is made all the more inevitable by the anomalous fact that the problems of minority shareholder protection that mainly concern Professor Cary usually arise not in the context of giant enterprises but in the more entrepreneurial and less professional environment of small and middle-sized companies.

Finally, account must be taken of the dreary fact that any federal minimum-standards statute would be accompanied by some new administrative apparatus, inside the SEC or elsewhere. The public, scholars, and even some government officials are showing increasing alarm and ire at the burgeoning of federal bureaucracy, ever-expanding reporting requirements, and intensified oversight from Washington, D.C. New federal legislative initiatives will undoubtedly be required to deal with problems of national moment, such as energy conservation and urban rehabilitation. But the presumption should be against federal intervention, and the corporate procedural questions that inspire Professor Cary's proposal can hardly be viewed as a national exigency.

In any event, whatever one's views on these matters, it should be observed that unlike most corporate critics, those of species VII are focused squarely upon true questions of corporation law. 


\section{H. Corporate Reform Species VIII}

A small group of critics of the American corporation adopts an eighth position that is even more explicitly ideological than that of the corporate democrats. Species VIII takes as an immutable axiom that for all institutions and for all time, the only institutional decisions that are legitimate are those that are arrived at on the basis of a consensus of all persons who have an interest in or are affected by the outcome. Thus, in their view, a board of directors of a corporation should not be allowed to decide to close a plant, since many other people will be affected by that decision. The solution usually proposed by species VIII critics-under the bland name "co-determination" -is that boards of directors should be required by law to include representatives of labor unions. It is pointed out that a variant of this feature has been introduced in Germany and is on its way in Great Britain.

One immediate question raised by this proposal relates to its internal philosophic consistency. If one were truly serious about including on a board of directors representatives of the various parties who have an economic interest in the enterprise, then it would include not only representatives of shareholders and employees but also representatives of lenders, suppliers, customers, contractors, lessors (and lessees), municipalities, states, school districts, charities, the U.S. Treasury, etc., all of which have a stake in the enterprise's income stream. Would all these groups be enthusiastic to see their interests guarded by labor union representatives?

But assuming that only representatives of unions should be added to the board, which union should it be, especially in the case of a company operating in diversified lines of business and in many parts of the country? Much of the American labor union structure continues to be craft based, unlike the unions in Europe; U.S. unions are more decentralized, and the interests of the local and the national often diverge; and U.S. unions have not historically developed as a centrally disciplined political party. And what of the fact that only a small minority of American workers belong to any union, despite the strong legal protections afforded to union organization?

But the split-board concept is faulty at a more fundamental level. Must special-interest participationism be accepted as a universal axiom to be applied unthinkingly to every form of organized human behavior? Aside from the question of its wider application to other institutions (armies, churches, schools, ship crews, courts, etc.), the core of the question as addressed to commercial enterprises is whether one recognizes and accepts that the commercial corporation-whether small or large-should be first and foremost an organization designed to operate efficiently to produce goods and services for the society, rather than a political organization designed to maximize political expression. To the degree that the managerial and decisionmaking structure of the incorporated enterprise is altered to resemble a New England town 
meeting, a Quaker consensus session, an Italian Parliament, or a two-party power negotiation, the capacity of the enterprise to carry out its basic economic function cannot fail to be impeded.

It is undeniable that social controls must be externally imposed on the conduct of large-scale enterprises. Those constraints can be strengthened, added to, or removed by legislatures, public agencies, and courts as circumstances and experience require. Even if particular controls are onerous, misguided, costly, or arbitrarily restrictive, if the modern incorporated enterprise is allowed to compete and have access to capital and resources, it can within remarkably wide limits adjust, adapt, and innovate to do an efficient job of economic production and distribution. But if the internal anatomy of the corporate enterprise is operated upon by an injection of divisive politicization, the predictable result will be to immobilize its decisionmaking capacity and to drag down the productivity of the U.S. economy to the detriment of all Americans and of other interdependent economies. In the special history of this country, the American labor movement has seen the situation and its own interests exactly right: its principle has been to let the managers make the money-and then do what can be lawfully done to take it away from them. For millennia, mankind has known that it can collect any number of goose eggs over time so long as it does not keep the goose from laying them.

Seen from this perspective, the role of common shareholders as the ultimate constituency of the corporation makes a great deal of sense. Unlike any of the other constituents who tap the income stream of the enterpriseworkers, creditors, tax collectors, suppliers, etc.-the common shareholder is playing for the entrepreneurial margin and only the entrepreneurial margin. Nothing so clears the mind and sharpens his taste for efficiency as the recognition that everyone else gets paid ahead of him and that he gets nothing unless there is something left over. No other constituency of the enterprise has the same incentive to achieve a high level of efficiency for the enterprise as a whole, since the economic interest of each other constituency is narrower or has a limiting cap on it or runs directly counter to the interest of the aggregate enterprise in cost control. Shareholders-particularly the professional, sharp-eyed investors with a nervous focus on the bottom line-perform a vital function for the enterprise and for the efficiency of the economy as a whole.

It is the responsibility of the board of directors and management of an enterprise, and it is to the special economic interest of the common shareholders, to attend to the operating efficiency of the enterprise as a whole. No other group has that perspective of the aggregate. To lodge within the board of directors a cell whose commitment is to a single constituency of the enterprise-whether to employees, lenders, consumers, or any other grouprather than to the interest of the aggregate enterprise is a certain way to 
dilute and in time to destroy the feature of the corporate form that, more than any other, has accounted for its extraordinary economic success.

National politics affords a familiar parallel on this point. The single most difficult problem dogging our federal government emerges directly from its character as a system of pluralistic representation of local geographic, economic, ethnic, and religious interest groups. Such a system must operate by tradeoffs, logrolling, and transient coalitions. In such a setting, the elected representative who would prefer to take the perspective of the interests of the nation as a whole will sometimes find that position to be in conflict with particular narrow interests of his home constituency. In such a situation, to stand for the good of the whole is to court local political suicide, an unwelcome option for most officials. As a result, it is extremely difficult for the President, the only elected official with a nationwide constituency, to persuade members of Congress to take action which the nation as a whole needs but which is unpopular in their home districts. Recent executive-congressional struggles over local dams and a long-term energy program are merely current illustrations of the problem. In national politics, national symbols and patriotism can to some degree be appealed to as a counter to the centrifugal tendencies of parochial interest. Little or no analogous emotional commitment exists within commercial enterprises. Introduction of subconstituency representation into the corporate decisional process would cause it to deteriorate rapidly into logrolling, an attitude of "I've got mine, Jack," and a general disregard for overall efficiency.

It is part of the strength of our present corporate form and a part of the strength of our national economy that corporate managers and directors who are answerable to shareholders can, when all other reasonable means fail, take the unpleasant step of shutting down an uneconomic operation. In the interest of aggregate efficient use of resources, both for the enterprise and the economy as a whole, a plant should be shut down when it cannot be made competitive. Any arrangement that keeps an unprofitable plant operating simply redistributes the loss to others and burdens some other part of the economy. That is not to say, however, that the burden of the shutdown should be callously dumped upon the local employees and the local community. The company should do what it can responsibly do to cushion the event by advance notice, by seeking to introduce new jobs in the locality, by retraining, by transferring personnel to other divisions, and so forth. Even more important, we should long ago have developed better governmental and social techniques for dealing with shutdowns by stimulating new local employment opportunities, by retraining, and by easing occupational transition. That is a function for the society and the government. Economic change is continuous and cannot be halted. The task of the well-managed enterprise is to adapt quickly to, and take advantage of, changes when they occur; it is the task of government to smooth the adjustment. We must develop more effective gov- 
ernmental and social means to distribute the losses of such dislocations. If we do not, companies and their managements will be put under increasing pressure not to take managerial steps that are economically maximizing, and support will increase for changes in the corporate decisionmaking system that will discourage aggregate efficiency in the interest of avoiding local dislocation.

Corporate critics of group VIII differ from groups VI and VII in their premises, in their perception of the problems, and in their proposed solutions. But they join in centering their focus on the process of corporate governance.

\section{Corporate Reform Species IX}

Finally, the ninth group that seeks change in the nation's present corporate system takes as its watchword "management accountability." This group acknowledges the utility and efficiency of the corporate enterprise and wishes to retain and encourage these attributes. But it argues that in any soundly run institution everyone should be accountable to someone else; and that the leader of any institution who is accountable to no one, whose word is law, and who is not in jeopardy of removal from power will in time become arbitrary, arrogant, self-aggrandizing, prodigal, and despotic and will, further, lose contact with reality, isolate himself from unpleasant information, and make increasingly erratic judgments, to the misery of those around him and ultimately to the disaster of the organization which he heads. The fear of group IX critics is that the top officers of large-scale American corporations have achieved, or at least approximated, such a status of nonaccountability and that the situation is both dangerous and morally unacceptable. ${ }^{9}$

In the view of the author, these propositions of human psychology are valid. Indeed, those who agree with this author that the centralized strongmanagement system of the modern large-scale enterprise is essential to its economic effectiveness must recognize that on the other side of the same coin it is written that: (1) the society should set external legal ground rules for the behavior of enterprises; (2) the society should do what it can to distribute the human costs of economic dislocation; and (3) external and internal forces of accountability must be effectively brought to bear upon corporate managers. The question is whether the existing set of accountability constraints upon corporate management is in fact adequate. That is a key and central subject for public debate.

9. Concern about the issue of accountability of corporate management is, of course, not limited to those identified here as group IX. For instance, the recent furor about corporate payments overseas was grounded not only in disapproval of the payments themselves but in shock that some managements had been able to make them without anyone's knowledge and thus seemed to have been accountable to no one. As another example, corporate critics who press to strengthen the processes of shareholder democracy do so on the ground, If shareholders do not hold the management and directors accountable, then who will? 
Corporate chief executives are powerful figures within their enterprises, but not all-powerful. In most large-scale American enterprises substantial forces are at work inhibiting, inspiring, blocking, or mandating particular actions by the chief executive or threatening to eject him from office. The reality of daily life for the chief executive is typically quite different from the picture drawn by much of the literature in the field, predominantly written by academics or governmental staff persons with little personal business experience. Former SEC Commissioner Richard B. Smith caught the point well when he said in a recent address that the concept of ${ }^{10}$

unlimited power of the chief executive comes as something of a surprise to

[a] corporate manager, as on a given day, [he is] struggling withcapital allocation requests to his board;

the meaning of a covenant being pointed to by bank lenders as preventing something he would like the company to do;

a strike threat by union negotiators;

the next level of standards fixed in environmental statutes that have to be met;

a tender offer threat from a well financed company whose chairman called him last night to tell him that he had picked up $4.9 \%$ of the company's stock in the market;

increasingly probing questions from his outside directors at last month's board meeting;

multiple tax return dates within the next month;

auditors filling and overflowing his conference rooms to complete the annual audit;

a team of outside lawyers and accountants prowling the corridors in the last stages of a sensitive payments investigation;

he and his subordinates scurrying around for new, or at least less expensive and more assured, energy sources;

trying to guess the inflationary impact created by the federal government on several long-range decisions he has to make;

his lawyers telling him about the new law or regulation with which he must now comply;

financial analysts who have just estimated a downturn in his next quarter's earnings;

a local zoning body that has ruled against a needed expansion of one of his major plants;

headhunters seeking to take his two best operating officers;

an underwriter who is advising him that this is not the time to raise equity capital;

the comptroller who has just announced a technological break-through that threatens the future sales trend of his most important product ...

The list is almost infinite for this person whose power [is said to be absolute].

Mr. Smith's reference to the financial analysts deserves special note. Analysts and financial commentators do not hold the same life-and-death power over managements and enterprises that drama critics often hold over

10. Smith, Federal Corporate Law, 10, 11 (unpublished remarks before the Association of the Bar of the City of New York, May 9, 1977). 
playwrights and plays, but there are similarities in the relationship. A company's earnings per share, stock price, reputation for financial soundness, and growth prospects are to its corporate managers as earned-run averages, batting averages, and coach's evaluations are to baseball players. Financial analysts and commentators, studying a company's reports in scrupulous detail, regularly serve up in public print evaluations of the performance of its executives; professional institutional investors register their evaluations directly by buying or selling or avoiding the company's securities. These clinical outside analyses help inform the company's board of directors, shape the market's estimate of executive performance, and significantly condition the opinion of executive peers, of persons serving on other boards, of directors, and of other professionals. Most corporate executives are acutely sensitive to the estimate of these constituencies and strive mightily to gain their good opinion and avoid their low esteem. That is the essence of accountability. And it is no accident that almost every chief executive of a major company constantly watches the market price of his company's shares, which, with the price/ earnings ratio, keeps daily score on the executive's performance.

Unmentioned in Mr. Smith's list is another factor that significantly conditions the executive's power. Seldom can the chief executive of a big company issue orders at whim and expect them to be followed. Large organizations are large organizations whether in the private or public sector. Every successful executive must be acutely mindful of the loyalty networks below him; of the capacity of the employees at all levels to block implementation of action which they do not approve; of pervasive bureaucratic conservatism; of the risk of precipitating resignations, transfers of allegiance to competitors, strikes, and general low morale; and of the independence of many employees who are dedicated to high-quality performance and who will refuse to comply with, and perhaps report to authorities or to the press, executive conduct which they find reprehensible. Contrary to popular impression, the successful corporate executive today is far less a despotic battle chieftain than a skilled orchestrator of committees, mediator among warring departments, practicing psychologist, public spokesman, salesman, negotiator, personal charmer, public affairs analyst, long-view thinker, diplomat, and teacher. The job of corporate chief executive requires these skills (in addition to a good business head, a competitive nature, high energy, experience, and a psychological capacity to make close judgments and sleep anights) precisely because there are so many limitations on his power and because there are so many constituencies that must be dealt with successfully if the enterprise is to prosper. Not often are all these attributes found in one person. When such persons come along and are identified through performance, they are inevitably in great demand, as star performers in other fields are in great demand, and the marketplace runs their compensation up to high figures.

There seems to be a time lag between reality and the accepted image of 
the unremovability of the corporate executive. Of late hardly a day passes on which the financial pages do not report the sudden departure of high executives from major companies. Managements do get fired these days, and not infrequently. Sometimes chief executives are displaced at the initiative of the directors, or some of them; occasionally an inside executive coup is successful; in some cases a critical financial press plus the weight of unhappy shareholders, individual or institutional, can bring down the roof. The circumstances surrounding these downfalls are not usually publicized, and they are most often explained as the result of "personal plans" or "personality differences" or "policy differences." But the outcome is the same. The corporate executive's seat is not nearly as secure as it once was. When to this insecurity is added the ever-present risk of outside takeover and management succession by boarding party, the executive may be forgiven for finding irony in allusions to his omnipotence and lifetime tenure.

Finally, the image of the all-powerful corporate executive developed in a day when corporate disclosure requirements were much weaker than they are today. Over the past fifteen years the SEC, the courts, the stock exchanges, and the auditors have, step by step, raised the water table of disclosure for large-scale enterprises. Recent revelations of illegal or questionable corporate payments overseas were all the more shocking because the payments had not been detected by the auditors. Though the magnitude of these transactions was not material compared to the scale of the assets and operations of the enterprises, the malodorous character of the payments led to a demand for disclosure, just as the special character of executive compensation and insider transactions has led to special rules of disclosure. The aftermath of the publicity surrounding questionable payments has inspired new disclosure requirements and new criminal sanctions; thus one more step, based on experience, has been taken to make executive behavior and enterprise conduct accountable to the scrutiny of the public eye.

The issue of executive accountability is thus not whether executive accountability is essential-it is-or whether some processes of accountability are functioning - they are-but whether those processes are working well enough, whether they can be improved so that they work significantly better, and whether additional machinery is needed.

Reflection on the content of the concept of accountability reveals that it contains several quite different components, each of them important and each perhaps calling for special processes of monitoring, reporting, review, or check and balance. Consider the following corporate situations which raise four different aspects of the problem of accountability:

(1) A company's officers improperly line their own pockets with assets of the company or its shareholders by self-dealing contracts at unfair prices, by paying themselves undeserved compensation, by trading in the company's stock on inside information, or the like. 
(2) In a misguided but unselfish effort to advance the interests of the company, its officers lead the company to violate the law, to infringe standards of decent business practice, or to behave in a socially irresponsible manner.

(3) Through laziness or incompetence, the company's officers operate the enterprise inefficiently and let it go to pot financially.

(4) The board of directors of the company fails to exercise due care to keep itself informed about the company's affairs; or fails to exercise due care to prevent management's cheating, illegal conduct, poor profit performance, or reprehensible social behavior; or fails to exercise due care to see to it that appropriate timely disclosure about the company's affairs is made to the public, the market, and the appropriate authorities.

To enact laws against these different categories of blameworthy corporate and managerial behavior is helpful, but not in itself enough. Prosecution can catch only a few evildoers, and it also has the disadvantage of coming after the fact. The criminal sanction is also clearly inappropriate to deal with simple managerial inefficiency. What is needed is a set of built-in institutional arrangements that on a daily, ongoing basis prevent, or at least contain within tolerable limits, undesirable conduct or ineffective performance by corporate managers, directors, and their companies. To achieve that result while retaining the important advantages of our strong-management corporate system requires several conditions, some of which are external to the corporate enterprise, and some of which are internal to it.

Requisite conditions external to the corporation are: an effective SEC; honest and exacting public accountants; a competent and skeptical corps of financial analysts and commentators; and a body of rigorous legal doctrine invocable in shareholders' suits by an able corporate plaintiffs' bar. What are the facts? The SEC has been consistently vigorous and activist. The profession of independent accounting (with a little prodding help from others) has of late been experiencing, and is still experiencing, a major evolution toward more scrupulous procedures and greater independence from corporate management. The financial press and analysts have become increasingly sophisticated and gimlet eyed in recent years. The plaintiffs' bar is alive and well, and shareholder litigation flourishes, despite some recently demonstrated indispositions by the Supreme Court to continue to expand the reach of class actions and rule 10b-5. So far, so good.

The other two requisites of management accountability are internal to the corporate structure. They are a board of directors that is not controlled by management and a flow of reliable information. Those two elements are essential. If the strong-executive model of corporate governance is to be maintained, it must be accompanied by a flow of solid and honest data sufficient to permit management's stewardship to be evaluated in all respects, and that flow must go (in the first instance) to a board of directors made up of members who are able and willing to 
evaluate management's performance objectively from the perspective of the interests of the enterprise as a whole. Contained in that single sentence, it seems to me, is the crux of current policy questions about corporate reform.

In these two matters, as in almost all areas discussed here, reform has in fact been underway all around us over the last few years. The concept of the outside board on which a majority of the members are not current or former company officers has been steadily growing in acceptance and today is a feature of most publicly held companies. With increasing frequency nominating committees of the board, charged with the selection of nominees to be presented to the shareholders (and nearly always elected), are coming to be controlled by outside directors, as they should be. Audit committees have come to be required of companies listed on the stock exchanges, and it is increasingly accepted that such committees should be predominantly composed of outside directors. Increasingly it is becoming standard practice that the controller, the independent auditor of an enterprise (and the internal auditor, where there is one) should have a direct channel of access to the board's audit committee. ${ }^{11}$ Rigorous new guidelines for directors, developed by the American Bar Association, will soon be promulgated.

Though this situation is markedly better than it was even a decade ago, there is still room for improvement, and a good many questions merit study, argument, and experimentation. What else can be done to assure that outside directors are truly independent and serious about their responsibility as directors? Should they be paid more to increase their commitment of time and energy to the enterprise? Or would an increase in their income from the enterprise tend to put them in liege to the management? Should the board of directors or committees of the board be provided with their own staff resources? And if so, of what kind and how? How useful is the device of the nonofficer chairman of the board, a familiar arrangement in nonprofit corporations? High corporate executive compensation is a red flag to many persons, often taken as proof that the management is unaccountable to anyone and pays itself whatever it wants; what procedures can be installed to guarantee that execútive compensation levels are genuinely the product of bargaining and market supply and demand? Are existing incentives and disincentives for service on boards of directors and for effective performance by board members in proper balance? What can be done to assure the integrity and availability of the independent reporting channel of the outside and inside auditor to the audit committee? What additional information about the company's affairs, if any, should be made public and in what detail? What should be the

11. A statistical review of procedural changes in recent years appears in The Conference Board, The Board of Directors: Perspectives and Practices in Nine Countries (1977). See also The Role and Composition of the Board of Directors of the Large Publicly Owned Corporation (Statement of the Business Roundtable, Jan. 1978). 
jurisdiction of an audit committee? i.e., where is a line to be drawn (if at all) between inquiry into accounting matters and inquiry into the general quality of management's performance? Is the state of the remedy of shareholders' suits too restricted or too inviting to the irresponsible plaintiff's lawyer? Can any practical and administrable scheme be devised to broaden participation in the process for nominating directors? How can boards of directors be encouraged to do a better job of monitoring the economic efficiency as well as the morals of management, and to remove chief executives who do not perform effectively?

Despite the importance of these and many questions like them, the immediate need today is to disseminate to all large-scale enterprises the management accountability practices that are being employed at present by the most forward-looking companies. To bring about that spread of better practices may ultimately call for an orchestration of state corporation law, judicial doctrine, stock exchange regulations, informal standard setting by the associations of professional corporate advisers, and SEC and state administrative action.

\section{Conclusion}

A capacity for independent critical judgment by boards of directors and an adequate information flow-these should be the two key objectives of corporate reform for the present and near future. This task has not just been discovered. Nor does it arise from a crisis that has suddenly overtaken us. The job at hand is to make an extremely complex and diverse process work reliably every day in hundreds of enterprises throughout the nation. Our record for corporate reform has been remarkably good for the last thirty-five years and notably effective for the last ten years. That reform has been brought about by incremental modifications, by experience, and by changes in attitudes. So far, it has also been achieved without suffocating the corporate goose. We should continue to move forward along that line. There is every reason to believe that we can and will do so if we focus clearly on the real problems that call for reform, if we acknowledge the primacy of the economic function of corporate enterprises, and if we keep firmly in view not only the problems of our corporate system but the benefits that the society as a whole reaps from its efficient operation. 